\title{
Extender Device
}

National Cancer Institute

\section{Source}

National Cancer Institute. Extender Device. NCI Thesaurus. Code C49944.

A device designed to lengthen a structure. 